DOI: $10.17516 / 1997-1370-0362$

УДК $81 ’ 366.58=512.157=133.1$

\title{
Some Similarities in the Future Tense Indicative Mood Categories of the Yakut and Frech Languages
}

\author{
Lidia V. Vinokurova, Agafia D. Efimova \\ and Valentina I. Ivanova* \\ M.K. Ammosov North-Eastern Federal University \\ Yakutsk, Russian Federation
}

Received 07.11.2018, received in revised form 21.11.2018, accepted 05.12.2018

\begin{abstract}
The present article discusses some special features and ways of expressing actions together with the semantic and stylistic correspondences in the future tense forms in the Yakut and French languages. The object of our research is the comparative and typological study of the grammatical form correspondences in the future tense in the Yakut and French languages. The analysis shows that in order to represent modal and expressive verbal aspects, both languages use similar grammatical expressions to denote actions despite the differences in the grammatical structure of these future form expressions: the Yakut language has only one verbal form, while the French language has six grammatical forms.
\end{abstract}

Keywords: mood, verb, word-building, language grammatical structure, auxiliary verbs.

Research area: philology.

Citation: Vinokurova, L.V., Efimova, A.D., Ivanova V.I. (2022). Some similarities in the future tense indicative mood categories of the Yakut and Frech languages. J. Sib. Fed. Univ. Humanit. Soc. Sci., 15(3), 353-358. DOI: 10.17516/1997-1370-0362.

(C) Siberian Federal University. All rights reserved

* Corresponding author E-mail address: efaga@mail.ru

ORCID: 0000-0003-2466-5288 (Vinokurova); 0000-0002-6088-8801 (Efimova); 0000-0001-9325-6395 (Ivanova) 
According to its genealogical origin, the Yakut language belongs to the Turkic group of languages, whereas the French language belongs to Romance group of languages (Vinokurova, Efimova, Ivanova, 2017: 953).

In terms of its structure and typology, French is an analytical language, whereas Yakut is an agglutinative language. All the word-building processes in the Yakut language take place by adding affixes to the root form. In the complex tenses of the French languages the same process is made with the help of auxiliary verbs.

The indicative mood, which is the subject of our study, is expressed by one of the main verb forms in both languages.

The Yakut language is estimated to have ten verbal mood forms, which differ from each other in their morphological representations and modality. These are the indicative, imperative, conditional, probable, affirmative, modal, subjunctive, presumptive mood and the imperfect mood of an action being completed (Ubriatova, 1982: 305).

There are four grammatical mood forms in the French language: indicative, imperative, conditional, and subjunctive. The indicative mood in French and Yakut can be formed in all three tense paradigms: past, present and future. The future tense does not strictly manifest itself, unlike the past tense. The future tense in French denotes a future action, which can be regarded in two aspects: as a particular future action or as an indefinite future action. Both tenses form the basis for modal transpositions (Gak, 2004: 348).

\section{Future tense in the Yakut language}

Future tense (keler birieme) in the Yakut language is formed from the stem of - yiakh participle by adding the possessive affixes.

Below is an example of the conjugation of the positive form of the verb bar ('go', 'leave', 'depart', 'to set off') in the future tense, indicative mood.

\section{Sing. f.}

Pl. f.

bar-yiag-yim (I will go, I will depart) / baryiakh-pyt (we will go, we will depart)

bar- yiag-yin (you will go, you will depart) / bar-yiakh-hyt (you will go, you will bar-yiag-a (he will go, he will depart) / baryiakh-tara (they will go, they will

depart)

Singular form in the positive form of the future tense in the Yakut language has a phonetically contracted form which is used along with the full form: min baryiam, en baryiang, kini baryia. The main concept of the future tenses is to denote actions, which will happen in the near or distant future starting from the moment of speech, for example: sarsyn, teatrga baryiam.

According to its general meaning, the future tense in the Yakut language does not differ from the future tense in the French and Russian languages. For example: Elle sera professeur de la langue française ( $F r$ r). Kini frantsuzkay tyl uchuutala buoluo (Y). Je parlerai yakoute $(F r)$. Min sakhalyy sangaryam (Y). The future form in Yakut also serves to denote some other future tenses.

1) Future imperative: turun, agagytyn kytta balyktyy barsyahhyt (Y). (Get up, you will go fishing with your father (literary translation)).

If the imperative action comes from other people and not the speaker directly, an additional modal word 'ugu' ('they say') is added to the future form. For example: miigin kytta barsyang ugu ('They say you need to come with me').

2) A warning not to complete an action, which is undesirable from the speaker's perspective, in the future. For example, olus aydaaryman - oghonu ugugunnaryahhyt $(Y)$ ('Don't make too much noise - you will wake up the baby').

3) A polite request to complete an action. For example, tukaam, oghuskun killerien duu. Tymnyy olustaabyt (Y). (Let's take the bull inside the barn, shall we? It got much colder).

\section{Future tense in the French language}

Unlike the Yakut language, where the future tense has only one grammatical form, the French language has six grammatical forms to denote the future tense. It can be simple (futur simple, futur dans le passé (future-inthe-past)) and complex, which is formed using the auxiliary verbs 'avoir' ('to have') and

depart) 
'être' ('to be') (futur antérieur (future perfect), futur antérieur dans le passé (future perfectin-the-past)) and also using a half-auxiliary verb 'aller' (futur immédiat (future continuous) and futur immédiat dans le passé (future perfect continuous)). Among them there are some future tenses which are mainly used in spoken form (future simple, future continuous, future perfect), some are used in both the spoken and written form (future perfect, future perfect continuous) (Tarasova, 2000: $365)$.

In our opinion, the functional characteristics of various modal forms of the basic future tenses meanings in the Yakut language correspond to the functional characteristics of all the six grammatical forms of the future tense in the French language.

\section{Futur simple}

Futur simple is normally used to denote a future action that the speaker is expressing at the moment of speech (Popova, Kazakova, 2011: 365), (Kostetskaia, 2002: 156). Futur simple is formed by adding the $-a i,-a s,-o n s,-e z$, -ont endings to the infinitive forms of almost all the verbs of the $1^{\text {st }}, 2^{\text {nd }}$ and $3^{\text {rd }}$ groups. For example: parler (sanar, kepset) - je parlerai; finir (byut) - je finirai, min butuegyum; sortir (tagyis) - je sortirai, min takhsyagyim. Some verbs of the $3^{\text {rd }}$ group have special forms in the future simple: être (buol) - il sera, kini buoluo; aller (bar) - il ira, kini baryia; faire (ongor) - il fera, kini ongoruo; savoir (bil, sataa) - il saura, kini biliye, satyia, etc. When used in context, Futur simple expresses a polite request: Je vous prierai de me prévenir. Tu mécriras nèst pas? En bighigini sereter ere. En miehe suruyaar duu? Futur simple can also express an order instead of Impératif: Vous emmenerez les enfants à l'ecole. Oholoru oskuolaga ildzher. Tu tairas-tu! Sanaraayahhyn! It can express a statement, a confirmation, an affirmation: Si tu es fatigué, depose-moi un moment dans l'herbe. Ça ira! Sylaydahhyna miigin ottooh sirge sytyaraar. Sep duo?

In his textbook Theoretical Grammar of the French Language, V.G. Gak notes that "the Futur denotes a future action which can be regarded dually: as a definite or an indefi- nite action. Both of these grammatical features serve as a basis for modal transpositions. Futur shows that the action is compulsory when it expresses an order (it replaces the imperative)" (Gak, 2004: 349).

In colloquial speech, future simple often denotes a presumption when it is used instead of the present tense: Voilà quelquiun qui lui rassemble, ce sera son frère ainé. Bu kiniehe maigynnyyr araaha iti kini ulahan ubaya byhyylaah.

The future tense form can convey a polite form: Je vous ferai remarquer que. Min eyiehe belieten etiem ete.

\section{Futur immédiat}

In the system of verb tenses in the indicative mood, the immediate tenses (temps immédiats) are used; they denote an action that directly follows or precedes another action. These are four tenses: futur immédiat (immediate future), futur immédiat dans le passé (immediate future perfect), passé immédiat (immediate past) и passé immédiat dans le passé (past perfect) (Gak, 2004: 862).

Futur immédiat is a tense which is used to express the nearest future action: Annette va préparer le déjeuner. Annett ebiet buharaary syldzar. Madame Labiche va venir. Futur immédiat is formed using the present tense form of the verb 'aller', which in this case serves as an auxiliary verb and is followed by an infinitive of a notional verb. This tense denotes a future action, which should immediately follow the moment of speech: Je vais ouvrir la fenêtre. Min sibiligin aany aryyayiam. Nous allons dîner. Bihigi sotoru ahyiahpyt. Je vais faire une piqûre de morphine. Min biligin ukuol turuoruom. In certain contexts Futur immédiat can express a polite request: Je vais vous prier d'attendre un peu. Kyratyk kuute tuherger kyordyohuyom ete. Tu vas préparer le dîner, hein? En ebiet buharyan duu? Allez vous coucher, les enfants, dit doucement notre père. Ogholor, baran utuyaaryn, dien aghabyt sibigineyde.

In colloquial speech futur immédiat can be used to denote any future action: Qu'est-que tu vas faire? Je vais parler au directeur. Tugu gynyahynyiy? Min diriekterdiin kepsetiem. 


\section{Futur immédiat dans le passé}

Futur immédiat dans le passé expresses an action which should immediately follow another action taking place in the past or an intention to complete an action. It can be expressed by using the imparfait tense of the verb 'aller' ('bar') and an infinitive of the notional verb. Futur immédiat dans le passé forms are usually translated into Yakut as 'sibiligin subu' which corresponds to the French 'J'allais vous de dire': Sibiligin min eyiehe ol tuyunan etiem. Quand j'allais partir, le téléphone a sonné. Subu baraary turdahpyna telephon tyahaata.

The Futur immédiat dans le passé tense replaces the Futur immédiat tense in indirect speech, if it refers to the past, for example: Mon ami a dit: "Je vais régler mes affaires" in French or "Dzhyalabyn biligin byhaaryam." diete doghorum in Yakut. - Mon ami a dit, qu'il allait régler ses affaires. "Dzhalabyn subu byhaaryam ete," - diete doghorum.

\section{Futur dans le passé}

The Futur dans le passé tense is formed using the infinitve of the notional verb and adding the imparfait endings: -ais, -ais, -ait, -ions, -iez, -aient. The Futur dans le passé tense denotes an action in relation to the past: Il gagna le Bois de Boulogne. Il s'y promènerait. Kini Bulon oyuurugar dieri tiiyie ete. Onno kuuleydie ete buollagha.

This verb tense is used instead of Futur simple in indirect speech, when it describes the past: J'ai répondu que je choisirais bien le moment. Toghoostooh tugeni kuuttuyom ete dien hardardym. Demain, il transvaserait le lait dans un chaudron de cuivre. Sarsyn kini uutu altan kytahha kutuogha.

\section{Futur antérieur}

Futur antérieur is formed using the auxiliary verb 'avoir' or 'être' in the futur simple tense and participe passé (Participle II) of the conjugated verb: j'aurai parlé, ils auront parlé, je serai venu ils seront venus (Moshenskaia, 2003: 253). Futur antérieur denotes a future action, which precedes another action in the future: Quand vous l'aurez vu, téléphonez-moi. Kinini kyodyohhutune miehe billererin. Elle va vous expliquer tout, quand je serai parti. Min bardahpyna kini barytyn ehiehe byharyia. This tense is used in the subordinate clauses of time, especially after such subordinating conjunctions as 'quand', 'lorsque', 'dès que', 'aussitôt que'. For example: Dès qu'il aura tout appris, il nous excusera. Yoydyoghune kini bihigini byrasty gynyia. Vous me direz ce que vous aurez compris. Yoydyotyohhytyne onu miehe eterin. The Futur antérieur tense is used in the main or in the independent clause: Quand tu viendras, j'aurai déjà quitté la ville. En kekerger min haiyy - yuyghe kuorakka suoh buolabyn. Roger viendra à midi. Moi, je serai parti. Roge kunus kelie. Otton min haiyy - uyeghe baryiam. The Futur antérieur tense in simple sentences expresses the completion of a future action: Dans un instant j'aurai fini de taper. Biligin bechetten butuyom. The Futur antérieur tense also highlights the swiftness of an action. The adverbial modifiers of time serve as indicators in such cases: Il aura bientôt traduit ce texte. Kini bu tiekihi sibiligin bechetten buterie.

\section{Futur antérieur dans le passé}

The Futur antérieur dans le passé tense stands for a future action, which precedes another future action and follows an action in the past. It is formed using the futur dans le passé form of the auxiliary verb 'avoir' or 'être' and participe passé of the conjugated verb. For example: Elle attendait son fils. Dès quìl serait revenue, elle lui parlerait de leurs projets. Kini oghotun kuutere. Oghoto kelleghine inniki bylanyn iyyitalahya. Jadis, il aurait tranché la question sans scrupules, sûr de son jugement, mais, à mesure quil vieillissait, il devenait plus prudent. Hahan ere kini beietiger olus erelleh buolan, munah boppuruohu birinchige suoh turgennik byhaarara, ol eren sahyran isteghin ayi sereghediyer buolbuta. The Futur antérieur dans le passé tense can be used instead of the Futur antérieur tense in indirect speech, if it refers to the past. For example: Il dit: "Je serai architecte, quand jaurai terminé mes études". Kini eppite: "Min uyorehpin buterdehpine arhitektor buoluom".

Thus, non-related languages can also serve as the objects of a comparative and typological study. Despite the differences in grammatical form structures of the future tense in Yakut and 
French (in Yakut there is only one verb form, whereas in French there are six verb forms), both languages use similar ways of expressing specific tenses of the future action in order to show modal and expressive shades of meanings which these tense forms contain.

\section{References}

Artamonov, V.P., Gavril'ev, N.N. (1997). Kratkii frantsuzsko-iakutskii slovar' [Short French-Yakut dictionary]. Moscow-Yakutsk, Inturreklama. Poligraf-servis, 544 p.

Gak, V.G. (2004). Teoreticheskaja grammatika frantsuzskogo iazyka [Theoretical grammar of French]. Moscow, Dobrosvet, 349 p.

Gavril'ev, N.N. (2002). Kratkii iakutsko-frantsuzskij slovar' [Short Yakut-French dictionary]. Yakutsk, Sahapoligrafizdat, $368 \mathrm{p}$.

Grineva, E.F., Gromova, T.N. (1986). Slovar' razgovornoi leksiki frantsuzskogo iazyka [The dictionary of French colloquial lexicon]. Moscow, Russkii iazyk, 638 p.

Kostetskaia, E.O. (2002). Prakticheskaia grammatika frantsuzskogo iazyka dlia neiazykovykh vuzov [Practical French grammar for not linguistic higher education institutions]. Moscow, Vysshaia shkola, $156 \mathrm{p}$.

Moshenskaia, L.O. (2003). Frantsuzskii iazyk dlia nachinaiushchikh [French for beginners]. Moscow, Vysshaia shkola, $253 \mathrm{p}$.

Petrova, T.I. (2008). Kratkii russko-iakutskii slovar' [Short Russian-Yakut dictionary]. Yakutsk, Bichik, 368 p.

Popova, I.N., Kazakova, Zh.A. (2011). Grammatika frantsuzskogo iazyka. Prakticheskii kurs [French grammar. Practical course]. Moscow, Nestor Akademik, 365 p.

Shcherba, L.V., Matusevich, M.I., Nikitina, S.A. (2004). Bol'shoi russko-frantsuzskii slovar' [Big Russian-French dictionary]. Moscow, Media, 561 p.

Tarasova, A.N. (2000). Grammatika frantsuzskogo iazyka. Spravochnik. Uprazhneniia: Uchebnoe posobie [French grammar. Reference book. Exercises]. Moscow, Inostrannyi iazyk, 373 p.

Ubriatova, E.I. (ed.) (1982). Grammatika sovremennogo iakutskogo literaturnogo iazyka [Grammar of the modern Yakut literary language]. Moscow, Nauka, $305 \mathrm{p}$.

Vinokurova, L., Efimova, A., Ivanova, V. (2017). Some similarities of present tense categories in indicative mood in modern French and Yakut languages. In $4^{\text {th }}$ International Multidisciplinary Scientific Conference on Social Sciences and Arts SGEM, 960 p. ISBN 978-619-7408-19-5 / ISSN 2367-5659. 


\title{
Некоторые схождения глаголов будущего времени \\ в якутском и французском языках
}

\author{
Л.В. Винокурова,А.Д. Ефимова, \\ В.И. Иванова \\ Северо-Восточный федеральный университет \\ им. М.К. Аммосова \\ Российская Федерачия, Якутск
}

\begin{abstract}
Аннотация. В статье рассматриваются некоторые особенности и способы действия, а также семантико-стилистические соответствия грамматических форм будущего времени в якутском и во французском языках. Объектом нашего исследования является сопоставительно-типологическое изучение схождения некоторых грамматических форм будущего времени в неродственных языках: в якутском и во французском. Анализ показывает, что для представления модальных и экспрессивных оттенков глагольных времен оба языка используют сходные средства способов действия, несмотря на разницу оформления грамматических форм будущего времени: в якутском языке есть только одна глагольная форма, а во французском - шесть грамматических форм.
\end{abstract}

Ключевые слова: наклонение, глагол, словообразование, грамматическая организация языка, вспомогательные глаголы.

Научная специальность: 10.00.00 - филологические науки. 